\title{
Sadivayal Village Development Model: A Smart Sustainable Tribal Hamlet for Community
}

\author{
Sreeni, K.R. \\ Amrita Vishwa Vidyapeetham, Coimbatore, Tamil Nadu, India \\ Corresponding author: krsreeni72@gmail.com
}

Received: 11 Feb., 2020

Revised: 13 Apr., 2020

Accepted: 27 May, 2020

\begin{abstract}
Under the concept of Amrita Self Reliant Village (Amrita SeRVe) has adopted Sadivayal village, Coimbatore, one of the remote tribal villages of Tamilnadu, to develop it as first Smart Village. The village is situated $45 \mathrm{~km}$ away from Coimbatore District, having 46 families with an average population of 150 belongs to the Irula Community of Scheduled Tribes. Amrita SeRVe smart village focuses on how villagers utilize local resources in better ways, access to food and nutrition, education, healthcare, access to clean water and sanitation. In Amrita, SeRVe agriculture acts as a catalyst for development and capable of addressing unemployment, health, education, gender equality, and boost income. Sadivayal became our first organic agriculture certified village in Coimbatore District, Tamil Nadu, which applies the standards set by the National Programme for Organic Production (NPOP). In 2018, the village beame open defecation free (ODF). The paper highlights some of the notable Model Village efforts of India and what have been their development indicators in the backdrop of Sustainable Development Goals (SDG's). Also, what Amrita SeRVe acheived compared to model Village initiative of Central Government: the Sansad Adarsh Gram Yojana.
\end{abstract}

Keywords: Amrita Self-Reliant Village, Organic Farming, Smart Village, Sustainable Village

There are around 649,481 villages in India, according to Census 2011 in which there are 1,45,000 tribal villages; so there is a need for nourishing and develop the tribal villages as a smart village. $68.9 \%$ of our population lives in villages (Census 2011) and it is expected that half of our population would be rural even in 2050. After seventy years of independence, still, there is a significant gap between rural and urban India. Despite there being several past initiatives by governments at all levels - Central, State and local, many of the policies have failed, schemes haven't reached rural people, and level of improvement has not kept pace with the expenditure of the government. Lack of a holistic focus on the villages as a unit is some of the causes.

\section{Where is the Alternative Model?}

\section{Amrita SeRVe Smart Village}

Amrita SeRVe was launched during on Mātā Amritānandamayī Devī (Amma's) 60 ${ }^{\text {th }}$ birthday in September 2013 and ushered in sustainable development in village clusters across India. Since then, we have focused on areas in which to begin a series of changes that start from basic needs; safe

How to cite this article: Sreeni, K.R. (2020). Sadivayal Village Development Model: A Smart Sustainable Tribal Hamlet for Community, International Journal of Inclusive Development, 6(1): 23-29.

Source of Support: None; Conflict of Interest: None (c) 9 
and nutritious food, education, health for all. Teach villagers the skills to live in communities, share their resources and work in a group so that the village economy will robust and become self-reliant. Villages are basic units that decide the GDP of India as they are the providers of most of the nation's food supply. Smart Village India gets its foundation from Mahatma Gandhi's vision of Adarsh Gram (model village), promotes the concept of integrated rural development by involving the majority of the population after Independence in 1947. Hence, for the overall development of the country, the focus must be given to the grass-root level, and that means the core areas should be agriculture through which all other parameters such as health, education, job, and economy can be achieved.

Real strength should come from within. If we are going to rely only on the external, there is no stability. In the olden days, the people of India's villages knew their inner strength. They were also completely in tune with Nature which leads to a full harmony of being.

It is our villages that sustain us by providing those who live in cities with the nourishment needed to survive. However, today, we are just exploiting villages and casting them aside. It is time to acknowledge that our villages are our very foundation and move forward with one heart and one mind to protect and serve them.

\section{- Amma}

\section{Working Model}

The Mata Amritanandamayi Math (MAM) selected 101 villages throughout India with the goal of holistic development and helping them to become self-reliant role-model villages for the country. By 2017, Amrita SeRVe had started its work in twenty one states. Village Coordinators from Amrita SeRVe looks after the activities in each village. Separate flagship programs targeting different cross sections of village population were introduced such as AMMACHI Labs that provides skill training program to rural women and arrange internship program for students from various streams to know India better by staying and learning from villagers; Amrita CREATE which educates rural and tribal people through tablet technology and appoints tuition teachers; The Amrita Center for International Programs (ACIP)-which is the central point for international academic relations at Amrita University and that sends foreign students to the village for research projects. The role of village coordinators in Amrita SeRVe "First learns from villagers their tradition, culture, beliefs, and way of life and don't try to impose anything on them". -Sri Mata Amritanandamayi Devi (Amma). India is a land of "Unity in diversity" and villages represent true India. When village coordinators work in villages they have to work with responsibility and sensitivity towards social, cultural, economic and environmental issues.

Amrita SeRVe mainly focuses on seven areas: Health, Water and Sanitation, Education, Agriculture, Income Generation, Eco-Friendly Infrastructure and Self-Empowerment.

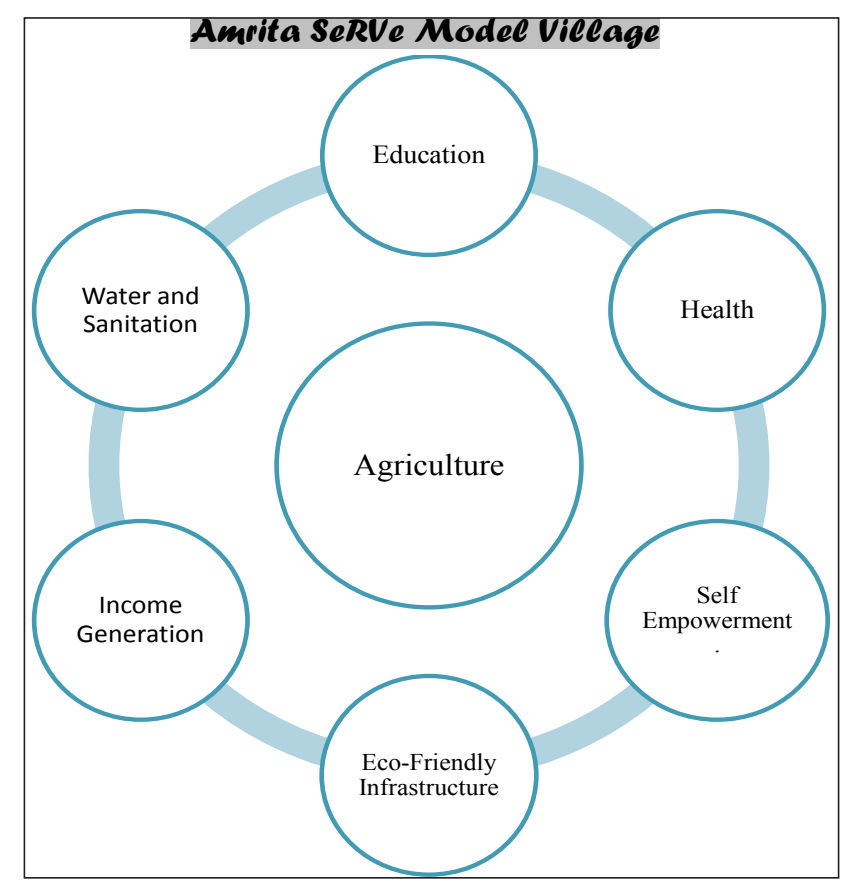

Fig. 1

Details of Model Village

\begin{tabular}{cc}
\hline Country & India \\
\hline State & Tamil Nadu \\
District & Coimbatore \\
Block & Thondamuthur \\
Panchayat & Madvarayapuram \\
Adopted Village & Sadivayal \\
Agency & Amria SeRVe \\
Language & Tamil \\
Religion and Caste & Hindu, ST \\
Community & Irula \\
Pincode & 641114 \\
\hline
\end{tabular}




\section{Working Culture}

- Village Coordinator (VC) works as the interface to the villagers in all development process.

- Conducting the participatory rural appraisal (PRA), base-line surveys, training and capacity building programs.

- Ensuring women's participation and priority should be given to the weaker section of the society and their requirements are adequately reflected in each program.

- Preparing detailed reports on local resources available for development including water, land, and energy uses.

- Undertaking engineering surveys, preparing engineering drawings and cost estimates for any structure to be built.

- Facilitate to open bank accounts, birth and death certificate, health cards, ration cards, and Aadhar card.

- Facilitate to start Village Development Committees (VDC's), Self-help groups (SHG's) and Farmers groups (FG's).

- Make sure that all institutional arrangements are made at the village level and to ensure people's participation by creating committees that are capable to solve various problems at the village level and administrative level. The committee also acts as a watchdog for program implementation and oversees all the matters about the development of the villages.

\section{Aims of Amrita Smart Village}

- Homes to each household.

- Open Defecation Free village (ODF).

- Safe drinking water and regular power supply.

- Records of complete Household, Agriculture Land, Land deeds (Pattyam), Water Resources, Crop Pattern, Bank account, health cards, and applicable services and schemes.

- Development based activates should be approved by the village committee.

- Income generation activates should be implemented within the groups.

- Facilities to keep domestic animals.
- Awareness of government schemes such as Drip Irrigation, Solar Panels Lighting Systems on streetlights, etc.

\section{ATTRIBUTES OF SMART VILLAGE}

\section{Role of Village Coordinators}

\section{Maximum land use in Villages}

Bring maximum land under cultivation through proper irrigation facilities, using various government schemes, promoting and supporting a local variety of staple food grains using organic methods and proper marketing support.

\section{Need to Switch to Organic Farming as a Group}

Amrita VIVASAYAM SANGAM (Farmers group) farming initiatives are a huge step forward for impoverished farmers to work together and bring themselves out of serious debts. Sadivayal is a tribal village in Tamil Nadu and their farmers' group was the first such endeavor. Their first year together was 2016, and they, much to their surprise and satisfaction, experienced a profitable crop of organic rice.

The decision to experiment with organic was most definitely unknown terrain. The farmers in Sadivayal are now committed to taking it further. Agriculture with non-organic pesticides and fertilizers along with the practice of overusing land has severely damaged farmland across India. In some areas, the fields are no longer farmable.

Amrita SeRVe's Major Steps in Agriculture Organic agriculture was practiced at 35 acres of land at Sadivayal Village, Thondamuthur Block, and Coimbatore Districts where the population mostly constituted the tribal Irulas community in 44 households. In the absence of irrigation facilities, villagers primarily practiced rainfed agriculture, and once in a year, they cultivated rice. However, as agriculture production was not sufficient for most of the families to sustain them throughout a year, they resorted to daily wage labour activities in the nearby forest area. The main objective of the Amrita Farmers Groups is to improve the livelihood of poor and marginal farmers by organizing them into groups and helping them adopt innovative Agricultural activities and to improve the overall 
security of farmers- food, social, health, and safety. After various discussions with the farmer's groups, Amrita SeRVe (Amrita Self Reliance Village) team concluded that to enhance the income of farmers, group farming is the best method. The increase in their income could only be possible by group farming and the all-round support from various line departments using convergence method and the project investment which can lead to sustainable livelihood enhancement. Training the farmers on fertilizers, seeds will lead to agriculture activities that are economically independent and socially empowering. The convergence method is the need of the hour. On 09 May 2016, a resolution was passed at the village, where twenty most deprived families of the village were selected to start group farming and a bank account in Canara Bank was opened under the name of Amrita Vyavasayam Kulu. Together they defined the responsibilities and formulated guidelines for internal management. The Amrita SeRVe team too focused approach to addressing various needs of farmers. Starting with the activities like selection of seed, soil testing, seed testing, crop planning, water budgeting \& water conservation. Upon completion of the discussion, farmers began their activities on June 20th, 2016. Convergence and group farming In convergence, since the farmers themselves save seed for the next cultivation, there is no necessity for buying the seed from an external source. They also use cow dung and urine from their cattle which is free of cost to make bio-fertilizers and biopesticides. In addition to cow dung and urine, they need some fruits, jaggery, etc. to make biopesticides, which costs around ₹ 2000.00 for each of the farmers. Since the material costs for purchasing inputs are reduced, there is no need for external transportation. For labor-intensive work, labour is sourced from the farmers themselves who are working on their land, thus the amount spend on labour is also reduced. Even though the work required is the same in both convergence and outsourcing, the rate for the work per person is reduced by half, and the total amount also gets reduced by almost half the outsourcing amount. The total amount spent on outsourcing amounts to $₹ 58,000.00$, whereas convergence came in at $₹ 25,000.00$, reflecting a saving of ₹ 33,000.00 by group farming. The farmers, group gained confidence in November 2017 they started organic farming with a new vision to convert the whole cultivable land of the village of 40 acres to an organic farm. The nearby hamlet also drew inspiration and started cultivating Bhavani rice, which was once the traditional rice of Tamil Nadu. After this great success, the following year in 2017 and 2018-19 they decided to expand to 40 acres and have had surrounding villages express interest in learning from them and converting to natural methods of farming as well. By 2019 around five villages started cultivating Bhavani Rice. In Jan 2018 farmers received land deed (pattyam) and eligible for applying organic certification. Since 2018, Amrita SeRVe has been working with the Tamil Nadu Agriculture University to obtain organic certification via the Tamil Nadu Department of Organic Certification under the National Programme for Organic Production (NPOP). For this purpose, the farmers needed to get the soil and water examined by the Soil test department, Tamil Nadu Agriculture University (TNAU). The certificate covers the production of mixed vegetables, mango, and rice. The land is subjected to annual inspections for maintaining status. This empowers farmers to receive more value for their products and thereby increases their annual income. The projects are continued from the last three years is key to eradicating poverty, hunger, and malnutrition in the Sadivayail village. In 2020 Sadiayal village became the first Organic Certified village in Tamil Nadu. The Certificate is issued by the Department of Organic Certification, Tamil Nadu Department of Organic Certification, Tamil Nadu Agriculture Department under the National Program for Organic Production (NPOP).

\section{Role of Health Workers}

Rural healthcare is a major problem in India due to the lack of qualified medical practitioners, nurses, and staff. Primary health care centers (PHCs) are limited, $8 \%$ of the centers do not have doctors or medical staff, 39\% do not have lab technicians and $18 \%$ PHCs do not even have a pharmacist. Other issues like quality infrastructure, basic medicines and medical facilities, low quality of care, poor accountability, and lack of awareness brings the importance of health workers. To address the grim fact, Amrita SeRVe chooses community health workers from the community itself and gave them proper training on basic health and medical care 
within their community and also to inform the PHC doctors and health staff during an emergency. Train them to give awareness on various diseases to the villagers, monitor pregnant women and newborn children, and to conduct regular medical camps. In Sadivayal doctors and health, staffs are visiting frequently from nearby PHC hospitals, health card is maintained properly, children were the polio vaccine on time. If some emergency exists health workers will coordinate with doctors and took villagers to nearby PHCS or Government Hospital. Health workers always act as a bridge between villagers and Government Doctors. Every activity of health worker is monitored by experts at Amrita SeRVe and proper training were given to village staff.

\section{Role of Tuition Teacher}

In Indian villages, over fifty percentages of students are unable to complete schooling through high school. This is due to poverty, irregular attendance, lack of individual teacher attention, lack of interest in academic subjects, lack of guidance from parents, lack of proper transportation and meager family incomes. The huge dropout rates among women indicate that girls are needed for other activities such as looking after other siblings, domestic work and help with farm work. To reduce dropouts and bringing changes Amrita SeRVe selected a teacher from the community who provide regular tuitions to students in the village. Amrita CREATE has developed a project aiming to educate rural and tribal people in India through tablet technology. Community teachers engage students by sharing knowledge, help them to do home works, teach them good habits of cleanness and the importance of the environment. It helps to increase school attendants and reduces dropouts in schools.

Amma emphasizes that "There are two kinds of education: education for living and education for life. While education for a living is essential for success in the academic and material sense, and that is common. There is a missing link in modern education that's value-based education. To fulfill value-based education Amrita SeRVe started Gurukulam has been running for almost two months under the leadership of the village coordinators. Eight to fifteen-year-old students are taught in small groups. The framework for the curriculum includes aspects relating to the individual, family, community and societal units. The sessions include Indian authentic history, yoga, meditation, and values training such as patience and good behavior. The goal of the program is overall development so students can build character and attain success in their lives.

\section{Water and Sanitation}

About 550 million Indians are forced to defecate in the open due to lack of toilets. Many studies found that those households who build toilets prefer to continue to defecate in the open and that toilets provided by the government are especially unlikely to be used. To address the Sanitation issues, AMMACHI Labs an academic and research center at Amrita University that brings an interdisciplinary approach to addressing societal challenges, trained and empowered women to build toilets in villages and giving awareness to end open defecation. As part of a student's exchange program, ten students from the University of California, US, joined hands with the women of the village to construct the toilets. In 2017, AMMACHI Labs built ten toilets with the help of SHG women's and made the villages open defecation free. The women were trained and the daily wages were transferred to women accounts.

The World Bank estimates that 21 percent of communicable diseases in India are linked to unsafe drinking water and lack of hygienic practices. Success story Further, more than 500 children under the age of five die each day from diarrhea in India alone. On the $64^{\text {th }}$ birthday celebrations of Amrita University Chancellor Sri Mata Amritanandamayi Devi, Amma, on $8^{\text {th }}$ September 2017, the Jivamaritam project was launched. The Honourable President of India, Shri. Ram Nath Kovind, who was the chief guest of the event, inaugurated the Jivamritam Filtration System, the initiative to provide filtered clean drinking water to one crore villagers. Apart from that our village coordinator works on government schemes to get approval for check dams, farm ponds, solar pumps, and other water resources.

\section{Income Generation}

To empower women Amrita SeRVe engaged women in a variety of occupations and conducted many training programs such as toilet building, tailoring, making artificial jewelry, cloth bags, soap and 
detergent, papad and making reusable sanitary napkins. Amrita SeRVe supports them in marketing the products.

\section{Eco-Friendly Infrastructure}

We are encouraging massive afforestation - planting trees and restoring wetlands, natural resource management enhancing existing water management system that protects, restores, or mimics the natural water cycle and eco-friendly waste management system. Besides, cultural awareness classes teach how to live in harmony with nature, conduct cleanliness drives called the Amala Bharatam Campaign (ABC). Strengthening AYUDH - Amrita Yuva Dharma Dhara, organizing village -level sports, yoga, and meditation. Amrita SeRVe through its program aims to make every village self -reliant, safe and a better place to live

\section{Eco-Friendly infrastructure}

Amrita SeRVe recognizes the importance of sourcing raw materials locally and is exploring options to preserve traditional building methods while meeting modern requirements such as durability and cleanliness. Electrical demand is met either through the national grid or from independent renewable energy sources.

An emphasis on the importance of reforestation has led to an exploration of alternative fuels and more efficient heating methods for cooking. This not only compensates for the historic depletion of forests, but also improves groundwater levels, balances the local climate, and increases soil fertility. An ecofriendly infrastructure is a vision that emphasizes caring for our environment, the community, and all of society-today, tomorrow and for generations to come.

\section{Traditional building methods}

Amrita SeRVe is committed to preserving and developing traditional building methods. Every village community has special techniques using locally available natural materials. With the rise of Ferro-cement construction, these methods have been neglected, leaving very few knowledge-bearers alive from the olden days. Techniques ranging from clay tiles or thatched roofs to wood carving and mud buildings have endured decades with little or no maintenance. The greatest advantage of natural building materials over cement is the thermal properties of the houses. Regardless of whether it is burning hot or cold, traditional buildings tend to maintain a comfortable climate inside. On top of that, all the materials are non-toxic and therefore decay without harm if abandoned.

Amrita Vishwa Vidyapeetham is presently researching the methods of tribal craftsmanship. Blending contemporary practices with traditional techniques paves the way for innovation, especially in the area of weather resistance. As such, a team has begun exploring the benefits of the cutting edge construction material, Compressed Stabilised Earth Blocks (CSEBs), by constructing a model house on the Amrita's Coimbatore campus.

Because Amrita Vishwa Vidyapeetham's activities are closely coupled with in-depth research in the tribal villages, a vast number of advancements are expected in this area over the coming years.

\section{Amrita Kuteeram}

Since its inception in 1998, The MA Math's Amrita Kuteeram project has constructed more than 45,000 free homes for the poorest people across the country. When Amrita SeRVe started its work in the villages, some families did not have a proper home or the means to build one for themselves. For these families, 39 houses were constructed across eight states.

\section{Tree planting}

Over the last two centuries, the vast deforestation surrounding the villages has been so severe that today only a handful of isolated trees can be found in dusty fields or plain grasslands. This has a serious impact on agriculture and groundwater levels. Forests maintain soil fertility and cool local temperatures, allowing rainwater to sink into the ground. With their strong roots and branches, trees protect from landslides, flooding, and strong winds. Relentless forest clearing has resulted in receding forest boundaries, leading to droughts and extreme weather.

Amrita SeRVe supports tree planting through sapling subsidization and seed-ball preparations. Since planting a tree is a lifelong investment, the emphasis is placed on the environmental education of school children. For example, on World Environment Day ( $5^{\text {th }}$ of June), children were taught 
how to prepare seed-balls from a mixture of soil, cow dung and fertilizing herbs such as Neem. One or several seeds are enclosed in this mixture, dried in the sun, and then placed in any available space just before the onset of monsoon rains. This ensures the sprouting and growth of the plants.

\section{Renewable energy}

The most important end-use of electricity is the lighting of homes and streets. Houses in the villages often have very small windows, allowing only tiny amounts of natural light to enter. Especially at night, the rooms are immersed in darkness. Not only does the lack of lighting pose a challenge for women when they are cooking; it seriously limits the ability of school children to do their homework. An absence of light also carries a feeling of vulnerability, making walks along unlit roads an uncomfortable, and even dangerous, experience.

Although the government recently announced that the last Indian villages have finally been connected to the national grid, the supply is sometimes interrupted, usually at crucial times. In such scenarios, it is preferable to install small solar-powered home lighting systems, consisting of one small panel, a battery unit, and three lights. Amrita SeRVe, together with Amrita Vishwa Vidyapeetham's Center for Wireless Networks and Applications (WNA), has worked on low cost and durable models for villages. Both plants are selfsufficient, providing a steady supply of electricity to all the households in each community. These systems were pioneered by students and faculty of WNA while the actual work in the villages was facilitated through the Live-in-Labs ${ }^{\circledR}$ program together with Amrita SeRVe.

\section{Self-Empowerment}

Amrita SeRVe uplifts villages by facilitating activities to financially empower, socially reconnect, and internally harmonize the outer with the inner.

Amrita SeRVe empowers villagers, especially women, to open bank accounts, avail themselves of social-security schemes, and form Self-Help Groups (SHGs) to gain financial independence. Moreover, respected members from each community are encouraged to form a Village Development Committee (VDC), thereby creating a platform to identify, discuss and implement solutions to problems faced in their respective villages. It is primarily through such Village Development Committees that government support can be secured to benefit the entire village community.

Addressing the more subtle aspects of SelfEmpowerment, Amrita SeRVe facilitates regular yoga and meditation sessions and encourages the preservation of local traditions and rituals, including religious festivals, Poojas, and devotional singing. By celebrating together as a community and appreciating the joyful moments of life, worries are put aside and peace of mind is attained. For the youth, regular sports and games sessions, along with moral stories taken from a range of material, including India's most popular epic, the Ramayana, encourage a holistic development.

\section{CONCLUSION}

Villages are the back born of India and agriculture hampers the economic growth of the country. "India Lives in its village" stated by Gandhiji himself tells us that if you want to develop the nation, you must start development from the villages. Indian economy and growth depend on agriculture and a major part of GDP contributed through agriculture. Smart Villages like Sadivayal based on agriculture helps to reduce this migration by ensuring food and nutrition security, providing good health, education, employment, connectivity, technology, and clean environment. To meet all SDGs; the village plays a major role by exploring new opportunities for the rural population and support the concept of Rurbanization (Rural Transformation). Effective institutional convergence strategies among all departments jointly work with NGO's helps to develop model villages. The convergence planning will result in pooling of resources, both human and capital, transfer of technologies to one village pursuing commonly shared objectives which improves productivity.

\section{REFERENCES}

Anna Hajare, 2015. "Ralegan Siddhi Model," Ralegan Siddhi, Ahmednagar.

Freshwater David, 2000. "The Promotion of Employment and Economic Development," in TVA Rural Studies Program, Potsdam, Germany, June, pp. 2-16.

Garg, B.S. and Raut, A.V. 2015. "Adarsh Gram: A Gandhian Dream of Gram Swaraj".

Gandhi, Mahatma. 2010. Hind Swaraj (Centenary ed.). Delhi: Rajpal \& Sons. 
